Jurnal Ekonomi Syariah Teori dan Terapan p-ISSN: 2407-1935, e-ISSN: 2502-1508. Vol. 7 No. 9

September 2020: 1804-1817; DOI: 10.20473/vol7iss20209pp1804-1817

\title{
THE ALLOCATION OF TABARRU' FUND UNDERWRITING SURPLUS OF IPLAN SHARIA PRODUCT IN PT. ASURANSI JIWA GENERALI INDONESIA
}

\section{ALOKASI SURPLUS UNDERWRITING DANA TABARRU' PRODUK IPLAN SYARIAH DI PT. ASURANSI JIWA GENERALI INDONESIA}

Syarifudin, Nurlailah, Ana Toni Roby Candra Yudha

Sharia Economics - Faculty of Economics and Islamic Business - UIN Sunan Ampel Surabaya udinsyarif1109@gmail.com*, laila.nurlailah@gmail.com, anatoniroby@uinsby.ac.id

\begin{abstract}
ABSTRAK
Kehidupan yang semakin kompleks memungkinkan manusia dihadapkan berbagai risiko yang mengancam aktivitas keseharian bahkan jiwanya. Banyaknya masyarakat muslim di Indonesia menjadi asuransi syariah sebagai tempat yang tepat dalam memperoleh perlindungan atas risiko yang terjadi. Salah satu keberhasilan asuransi syariah dapat dilihat dengan pengelolaan dana tabarru' yang baik sehingga dapat memenuhi ketika peserta mengajukan klaim dan dapat mengalokasikan surplus underwriting dana tabarru' diakhir tahunnya. Sehingga tujuan dari studi ini adalah untuk menganalisis alokasi surplus underwriting dana tabarru' pada salah satu produk asuransi syariah di PT. Asuransi Jiwa Generali Indonesia. Penelitian ini menggunakan metode kualitatif deskriptif dengan strategi studi kasus guna memberikan gambaran detail terkait latar belakang, sifat, dan karakter unik dari alokasi surplus underwriting dana tabarru'. Hasil penelitian ini adalah diperolehnya kesesuaian pengalokasian dana tabarru' yang diterapkan oleh PT Asuransi Jiwa Generali Indonesia dengan fatwa DSN-MUI Nomor 53/DSNMUI/III/2006 tentang Akad Tabarru' dengan pembagian 50\% untuk cadangan dana tabarru', $30 \%$ diperuntukan kepada perusahaan dan $20 \%$ sisanya dikembalikan lagi pada peserta. Bersesuaian dengan ulasan sebelumnya mulai dari tujuan, metode penelitian dan hasil maka saran yang relevan dengan studi adalah adanya perhatian khusus pada pembagian surplus underwriting dana tabarru' pada peserta agar semakin banyak peserta yang tertarik menggunakan produk ini.
\end{abstract}

Kata Kunci: Asuransi Syariah, Alokasi Surplus Underwriting Dana Tabarru', Generali Indonesia

\begin{abstract}
An increasingly complex life allows humans to face a variety of risks that threaten daily activities and even the soul. A large number of Muslim communities in Indonesia are sharia insurance as an appropriate place in obtaining protection against the risks that occur. One of the successes of sharia insurance can be seen by tabarru' proper fund management so that it can meet when participants submit claims and can allocate tabarru' fund underwriting surpluses at the end of the year. So, the purpose of this study is to analyze the allocation of tabarru' fund underwriting surplus to one of the sharia insurance products at PT. Generali Indonesia Life Insurance. This study used a descriptive qualitative method with a case study strategy to provide a detailed description of the background MUI / III / 2006, nature, and unique character of the tabarru' fund underwriting surplus allocation. The results of this study have obtained the suitability of the tabarru' fund allocation which was implemented by PT Asuransi Jiwa
\end{abstract}

\section{Informasi artikel}

Diterima: 30-07-2020

Direview: 11-09-2020

Diterbitkan: 25-09-2020

*Korespondensi

(Correspondence):

Syarifudin

Open access under Creative Commons Attribution-Non

Commercial-Share A like 4.0

International Licence

(CC-BY-NC-SA) 
Syarifudin, et al/Jurnal Ekonomi Syariah Teori dan Terapan Vol. 7 No. 9 September 2020: 18041817

Generali Indonesia with DSN-MUI fatwa number 53/ DSNconcerning Tabarru' Agreement with a $50 \%$ distribution for tabarru' fund reserves, $30 \%$ was allocated to the company, and the remaining $20 \%$ is returned to the participants. Following previous reviews starting from the objectives, the research methods, and the results, the suggestion that is relevant to the study is that there is special attention to the distribution of tabarru' fund underwriting surplus to participants so that more participants are interested in using this product.

\section{Keywords: Sharia Insurance, Tabarru' Fund Underwriting Surplus Allocation, Generali Indonesia}

\section{INTRODUCTION}

An increasingly complex life allows humans to be exposed to various risks that threaten their daily activities and even threaten their lives (Ozili, 2019). Every risk that occurs cannot be eliminated but can be minimized. As a form of endeavor to minimize risk (Miftakhul Jannah \& Nugroho, 2019), guarantees are needed that can guarantee life, health (Tajerin et al., 2017), children's education (Habibi et al., 2017), happiness in old age to financial in the future. One of the right places to obtain protection for the risks that occur is insurance (Damayanti \& Mawardi, 2016).

Republic of Indonesia Law No. 40 of 2014 concerning Insurance in Article 1 paragraph (1), regulates that Insurance is an agreement between two parties, namely an insurance company and a policyholder, which is the basis for receiving premiums by insurance companies in return for a) provide reimbursement to the insured or policyholder due to loss, damage, costs incurred, lost profits, or legal liability to third parties that may be suffered by the insured; or b) provide payments based on the death of the insured or payments based on the life of the insured with benefits the amount of which has been determined and based on the results of fund management.

Insurance by some writers is interpreted as an agreement between the guarantor (insurance company) and the insured (participant) where the guarantor receives a premium from the insured and promises to pay a sum of the sum insured if the insured suffers a loss, damage, loss of the insured item or even loss of life.

The Pew Forum on Religion \& Public Life explains that Indonesia is the largest Muslim country in the world, which has a population of 265 million people, this number is very potential for Sharia insurance products (Hardiyan, 2019). Besides, this product is estimated to be able to develop around $15-20 \%$ per year (Miftakhul Jannah \& Nugroho, 2019). The existence of Islamic insurance continues to grow and compete in the insurance market in Indonesia (Fadilah \& Makhrus, 2019). Based on the Indonesian Sharia Insurance Association (AASI), the development of assets, investments, and contributions in 2016 are as shown in table 1. 
Syarifudin, et al/Jurnal Ekonomi Syariah Teori dan Terapan Vol. 7 No. 9 September 2020: 18041817

Table 1.

Development of Investment Assets and Contributions in Q1 2016

\begin{tabular}{|c|c|c|}
\hline Indikator & Growth (\%) & Q1 2016 \\
\hline Asset & $21,69 \%$ & 28.967 \\
\hline Investation & $23,64 \%$ & 25.726 \\
\hline Contribution & $10,25 \%$ & 2.753 \\
\hline
\end{tabular}

Source: Indonesian Sharia Insurance Association, 2016

Asset indicator $21.69 \%$, investment $23.64 \%$, and the contribution of sharia insurance $10.25 \%$ in Q1 experienced a slow increase in growth; This shows that interest in the sharia insurance industry is still relatively promising in Indonesia (Mapuna, 2019). In the future, AASI believes that Islamic insurance can penetrate the global market, develop (Tarora \& Juwita, 2016), and continue to experience fairly good growth (Yudha, Ryandono, et al., 2020).

The development of the number of the Islamic insurance industry in Indonesia until the end of 2017 can be seen in the following graph:

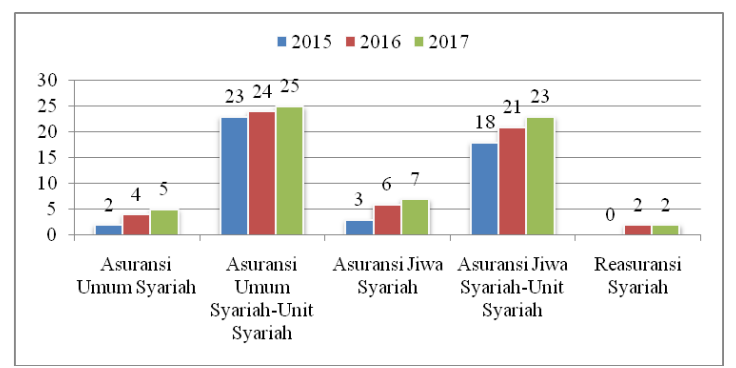

Source: Financial Services Authority, 2018

Figure 1.

The Development of Sharia Industry in Indonesia 2015-2017

The sharia industry, especially sharia insurance, experiences growth every year (Faozi, 2016). It was evidenced by the number of sharia general insurance that experienced growth from two to five companies in 2017 (Rijal, 2018), while sharia general insurance, which has sharia units, also increased from 23 to 25 companies (Annabi \& Ibidapo-Obe, 2017). Likewise, in Islamic reinsurance, which initially did not exist at all (Murti, 2017), in 2016-2017, there were two Sharia reinsurance companies (Hardyanti, 2019). This insurance shows its work in Indonesia (Miftakhul Jannah \& Nugroho, 2019).

The growth of sharia insurance has encouraged several companies to enter this business (Othman et al., 2016). Some immediately opened a full sharia insurance company, and sharia insurance office, with new product variants. In carrying out its operations, there are two contracts, namely the Tabarru' contract and the tijarah contract. Tabarru' contract that is all forms of contract oriented towards virtue and mutual assistance between participants (social-oriented). At the same time, the tijarah contract is all forms of business-oriented contracts (profit-oriented).

According to Sula (2004), in this case, the Islamic insurance company prepares an individual account for the help fund account (tabarru' account), which accommodates the contributions of participants who have been intended to help fellow participants. According to Sula (2004), an Islamic insurance company prepares a tabarru' account (tabarru' funds) to help. These funds will be paid to participants who make claims for risks that occur, both in the form of accidents and financial losses. Through this mechanism, participants contribute to participants who are at risk (Toni et al., 2019). This is as stated 
Syarifudin, et al/Jurnal Ekonomi Syariah Teori dan Terapan Vol. 7 No. 9 September 2020: 18041817

in QS. Al-Maidah: 2 which means, "... Moreover, please help you in virtue and piety, and do not help in sinning and trespassing ..."

Surah Al-Maidah verse 2 explains the obligation as a Muslim to help one another in matters of kindness. Where in sharia insurance, this is taken from tabarru' funds. In Islamic insurance, this is taken from Tabarru' funds. In managing tabarru' funds, Islamic insurance cannot be separated from underwriting management, which is a process of risk selection, which is then classified according to the level that can be borne by the insurance company (Damayanti \& Mawardi, 2016).

Tabarru' fund underwriting performance is something that must be considered because it is a benchmark of an Islamic insurance company in managing participant funds (Yudha, Pauzi, et al., 2020). High underwriting results can show excellent underwriting performance and vice versa. Tabarru' funds collected are used as generous contributions to be paid when the participant dies. If tabarru' funds are increasing in number and increasing every year, then the insurance company will get a surplus of underwriting.

The Financial Services Authority Regulation explains that the underwriting surplus is the difference from the total participants' contributions to the tabarru' funds plus the increase in reinsurance assets after deducting compensation/claim payments, reinsurance contributions and increases in technical reserves in a certain period. When there is a surplus of underwriting, some funds can be saved as tabarru' reserve funds, some for the insurance companies and participants by applicable regulations.

Also, the underwriting surplus can be used as a backup in the payment of claims in the future, so that the risk of default on participant claims can be minimized (Alifianingrum, 2018). Allocation of tabarru' fund underwriting surpluses' each insurance company is different. Sharia business units do one of them at PT. Asuransi Jiwa Generali Indonesia.

Generali Indonesia Life Insurance is one of the largest insurance providers in Europe, which was founded in 1831 in Trieste, Italy. Started its business in Indonesia in 2009 and has two sharia products, namely iPLAN (Insurance Protection Linked Auto Navigation) Sharia and iSALAAM. Since opening in 2017, iPLAN Syariah products have been widely discussed because they are unit link products so they can touch the realm of insurance and investment as well.

iPLAN Syariah products are becoming widely known and become one of the flagship products in this company (Hardiyan, 2019). In 2019, Generali Indonesia Life Insurance received the first tabarru' fund underwriting surplus, which reached up to 1.1 billion rupiahs. This then becomes the reason in this research to use iPlan Syariah products at PT Asuransi Jiwa Generali Indonesia as the research object. 
Syarifudin, et al/Jurnal Ekonomi Syariah Teori dan Terapan Vol. 7 No. 9 September 2020: 18041817

\section{LITERATURE REVIEW}

\section{Sharia Insurance}

Sharia insurance based on the National Sharia Council of the Indonesian Ulema Council (DSN-MUI) that sharia insurance (ta'min, takaful or tadhamun) is an attempt to protect and help one another or several parties through investments in the form of assets and tabarru 'which provides a pattern of return through a sharia-compliant contract to deal with specific risks (Soemitra, 2009: 245246). Agreements that are following sharia include not containing gharar (fraud), maysir (gambling), usury, zhulm (persecution), risywah (bribes), illicit goods, and immoral (Susyanti, 2016: 175).

Dahlan (1996) divided sharia insurance into several Arabic equivalent words, including (1) takaful, (2) ta'min, and (3) tadhamun. The three equivalent words can be described as follows:

\section{Takaful}

In language, takaful comes from the word ( $k a$ fa la) which means helping, nurturing, nurturing, giving a living, and taking over someone's case. Takaful is meant here whose root comes from the kafala-yakfulukafaasarana, has the understanding to bear, where one bears the other in various ways, among others, by helping him when he needs help especially those concerned or his family is stricken (Ali, 2016: 3-4).

2. Ta'min

At-Ta'min comes from the word amana, which means giving peace, protection, security, and free from fear and worry (Ali, 2016: 5). In line with the word of God in Surah Quraisy (106), verse 4 relating to the fulfillment of basic human needs and the obstacles encountered in meeting those needs.

3. Tadhamun

At-Tadhamun comes from the word dhamana, which also means to bear one another. This aims to cover the loss of an event or disaster that befell someone (Ali, 2016: 6). Therefore, the meaning of this tadhamun is mutual help (ta'awun), which means the necessity of helping one another by a group of people towards their siblings who are stricken by disaster.

Therefore, it can be concluded that sharia insurance is carried out by individuals or several people to strengthen social solidarity and responsibility towards Muslims by helping and bearing one another in order to create harmony and stability in social life.

In its implementation, lqbal (2005) mentions the primary function of sharia insurance as part of the implementation of Islamic law and the economic empowerment of the people. Based on its substance, sharia insurance has a function, for example:

1. In its implementation following Islamic law, sharia insurance functions as the benefit of the people, which refers to the foundations of sharia to protect and help each other. 
Syarifudin, et al/Jurnal Ekonomi Syariah Teori dan Terapan Vol. 7 No. 9 September 2020: 18041817

2. In national development, sharia insurance functions as an intermediary for the welfare and peace of the lives of people affected by the disaster as a form of risk transition from unplanned things.

3. In the management and utilization of the Ummah, shown by Islamic insurance indirectly involves several parties, starting with institutions that receive investment from insurance companies (from participant savings or tabarru' funds collected), even some hospitals and other institutions that work with Islamic insurance institutions.

\section{Contracts in Sharia Insurance \\ Tabarru' contract}

Derived from the Arabic language yatabarra'u, tabarra'a, tabarru'an, which means grants, benevolent funds, charity, or donations (Sula, 2004: 35). Tabarru' itself is giving someone to someone else voluntarily without expecting any return. Tabarru' funds on Islamic insurance are used as benevolent funds aimed at avoiding the practice of gharar that is forbidden by Allah as stated in the word of Allah QS. Al-Baqarah: 177:

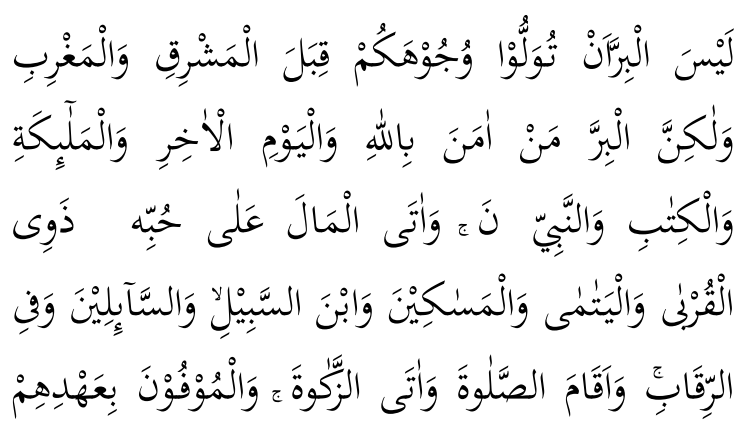

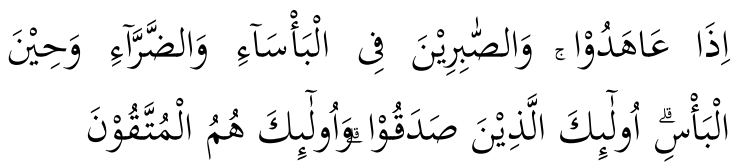

It means: "That virtue does not turn your face east and west, but it is a virtue of those who believe in Allah, the End Times, angels, books, and prophets and give treasure that is loved - it is to relatives, orphans, poor people, people who are on their way (travelers), beggars, and to liberate slaves, who perform prayers and pay alms, those who keep their promises when they promise, and those who are patient in poverty, suffering, and in times of war. They are the people who are righteous, and they are cautious. "

The paragraph above explains that doing actions in terms of the policy is an obligation or one of the commands of Allah SWT. With sincere intentions to accompany people in doing good things, a person feels helped and feels lighter in doing something substantial. This is what is by the concept of Tabarru' contract, where Tabarru' funds are used to help each other participants when there are participants who are struck down by disaster.

Tabarru' contract, which is used, aims as a form of contract that is used as a virtue for mutual help between fellow participants, not for a small gain. This contract is also referred to as a grant, where the intended grant is given to insurance participants who are being hit by a disaster so that in its application to Islamic insurance as a form to help each other, protect, guarantee and bear the 
Syarifudin, et al/Jurnal Ekonomi Syariah Teori dan Terapan Vol. 7 No. 9 September 2020: 18041817

risk when there are participants who experience an accident.

Not only that, but the objectives of the Tabarru' contract are also so diverse, among others, it can strengthen the friendship between participants who experience a disaster, mutual help, and help among fellow participants, foster an attitude of responsibility by giving a small portion that is intended for other participants when it occurs claims, and can avoid the attitude and actions that are indifferent and selfish so that it causes harm to other insurance participants.

The percentage of the tabarru' funds paid by each participant is undoubtedly different, and this is influenced by the age and duration of the agreement of the prospective participants of Islamic insurance. The longer the agreement period and the age of the prospective participants, of course, the tabarru' funds paid are also higher.

\section{Tijarah Agreement}

It is a profit-oriented or commercial purpose contract. Usually, Islamic insurance companies use the concept of this contract in the form of mudharabah. Mudharabah is a collaborative agreement between two parties, wherein sharia insurance, participants are owners of capital (shahibul mal), and sharia insurance companies as capital managers (mudarib). If the sharia insurance company benefits from the investment return, then the profit will be distributed to participants and the company according to the percentage agreed at the beginning of the agreement.

In addition to implementing mudharabah agreements, several agreements can also be used by Islamic insurance companies, such as musyarakah, walah, and wadiah contracts. In practice, this tijarah contract can be changed to a tabarru' contract when the participant's rights are held back, and the participant is willing to relinquish his rights so that the participants' obligations have not been completed (Amrin, 2006: 82).

The Concept and Allocation of Tabarru' Fund Underwriting Surpluses in Sharia and Conventional Insurance

There are differences related to the concept of underwriting between Islamic insurance and conventional insurance. Underwriting on conventional insurance must choose which risk object is covered or not. In other words, the underwriter will make an assessment that is based on all the risks posed to the company and is thought to benefit collectively. After that, the amount of premium and deductible value, etc. which is commensurate with the anticipated value of claims from the insured, management costs, and acquisition costs, are also determined by the underwriter. Furthermore, the most important thing is that they must obtain underwriting profits for the company (Qudsi, 2018: 34).

In contrast to the concept of underwriting goals in Islamic insurance, which provides a proportional and fair risk- 
Syarifudin, et al/Jurnal Ekonomi Syariah Teori dan Terapan Vol. 7 No. 9 September 2020: 18041817

sharing scheme between participants who are collectively relatively homogeneous. The hope from this rationale is that participants can help each other with mutual protection, so participants will feel safe and can enjoy the protection they need (lqbal, 2005: 34).

Article 4 POJK No. 72 / POJK.05 / 2016 concerning Financial Health of Insurance Companies and Reinsurance Companies with Sharia Principles explains that in sharia insurance, there is a term called surplus underwriting. Underwriting surplus is the difference between the total contribution of participants (policyholders) into the tabarru funds' plus the total recovery of claims from reinsurers and reduced by the payment of compensation/claims/benefits,

reinsurance contribution, as well as an increase in the technical allowance for a specified period.

According to Sholihin (2013), a surplus (deficit) underwriting is the difference between tabarru' funds used to cover the losses of participants by insurance companies with some risksharing contributions that were successfully collected in tabarru' funds. The deduction from the net contribution at the end of the year is then reduced by the total number of claims incurred. If the result of the reduction is positive, then the Islamic insurance company is in a tabarru' fund underwriting surplus.

If the Islamic insurance company is in a condition (tabarru' fund underwriting surplus) like this, then it can be treated as follows: (a) the entire surplus is used as a tabarru' fund reserve; (b) Some of the surpluses is included in the tabarru' fund reserve, and some are distributed to participants; or (c) part of the surplus is included in the tabarru' fund reserves, some are distributed to participants, and some is distributed to Islamic insurance entities (companies).

However, if the value of the reduction is negative, the insurance company has a tabarru' fund underwriting deficit, and the company must overcome the shortfall using a gardh (loan) agreement. Qardh returns to Islamic insurance companies will be taken from tabarru' fund underwriting surplus in the next period.

The underwriting surplus received by the participant must also fulfill many conditions listed in Financial Services Authority Regulation (POJK) No. 72/POJK.05/2016 in CHAPTER III Article 6 paragraph 4, as follows: (a) participants have paid contributions for the calculation period of the underwriting surplus; (b) the participant is not in the process of settling the claim; (c) the participant has never received a claim payment over the amount of the contribution allocated to the tabarru' fund; (d) the participant does not terminate the policy during the calculation period of the surplus underwriting.

\section{RESEARCH METHOD}

This type of research used in this study is qualitative research by collecting data, compiling, analyzing, and 
Syarifudin, et al/Jurnal Ekonomi Syariah Teori dan Terapan Vol. 7 No. 9 September 2020: 18041817

interpreting it (Arikunto, 2010: 3), to analyze the tabarru' fund underwriting surplus allocation on iPlan Syariah products at PT. Generali Indonesia Life Insurance requires data in the field in the form of data in the form of facts and accompanied by in-depth analysis by researchers. The research strategy used by researchers is case studies. The researcher uses a descriptive case study in this research in order to provide a detailed description related to the background, nature, and unique character of a case so that the objective is to analyze the allocation of surplus underwriting of tabarru' funds in iPlan Syariah products at PT. Generali Indonesia Life Insurance can be described in detail.

\section{RESULTS AND DISCUSSION}

\section{Generali Indonesia Life Insurance}

Generali Life Insurance Indonesia is part of the Generali Group, which is the largest life insurance company in Europe, which was founded in 1831 in Trieste, Italy. Generali has succeeded in building a Group that currently operates in more than 60 countries. Generali became one of the Top 50th smartest companies in the world, according to MIT Technology Review, and began to expand its wings in Indonesia.

Generali Indonesia has obtained a license to establish a sharia unit listed in the Decision of the Members of the Board of Commissioners of the Financial Services Authority (OJK) Number KEP-110/NB.223/2017 regarding Granting of Sharia Unit Establishment Permit and has become a member of the Indonesian Sharia Insurance Association (AASI) as proven by AASI Membership Certificate No. Reg: A.0029.2017.

Eikema (2020) explained that Generali Indonesia has its head office located in Generali Tower 7th Floor, Gran Rubina Business Park, Rasuna Epicentrum Area on Jalan HR Rasuna Said Kav C-22, Karet Kuningan, Setiabudi, South Jakarta 12940. The Generali Center Surabaya is located at Intiland Tower, 3rd Floor, Jalan Panglima Sudirman No. 101-103, Surabaya 60271. At present, the agency and Bancassurance of Generali Indonesia Life Insurance have spread to more than 40 cities throughout Indonesia.

Generali Indonesia Life Insurance has a wide range of products, ranging from iPRIME, iPLAN, iPLAN Sharia, GEMILANG, Generali Flexi Optima (GFO), We Flexi Pro (WFP), CEMERLANG, and iSALAAM. In the Islamic unit, PT Asuransi Jiwa Generali Indonesia only has two products, iPLAN Syariah (which began launching in the 4th quarter of 2017) and iSALAAM (which was only launched in the 4th quarter of 2019).

1. iPLAN Sharia

It is a life insurance product unit sharia link that has an extension of the Insurance Protection Linked Auto Navigation Syariah specifically designed to optimize protection and maximize the investment portion so that participants can get maximum returns with regular premium payments based on sharia principles. 
Syarifudin, et al/Jurnal Ekonomi Syariah Teori dan Terapan Vol. 7 No. 9 September 2020: 18041817

Anggraini (2020) added that this product has various advantages, including (1) ease of representation, (2) profit-sharing system (tabarru' fund surplus underwriting), and (3) bonus of healthy living-bonus 85.

2. ISALAAM

It is a life insurance product with regular contribution payments under sharia principles and has an insurance period of up to 99 years. This product provides insurance benefits in the form of the death benefit, benefit from the exemption of contribution if the policyholder dies, and Blessing Benefits 99 (Generali Indonesia Sharia Unit, 2019: 1).

\section{Analysis of Tabarru' Fund Underwriting} Surplus Allocation IPLAN Sharia Products in Generali Indonesia Life Insurance

Generali Indonesia Life Insurance is a type of conventional life insurance that has a sharia unit with an establishment permit from the Financial Services Authority and the DSN-MUI Fatwa. In its operations, Generali Indonesia Life Insurance uses two types of contracts, namely the tabarru' contract, and the tijarah contract.

Tabarru' agreement, which is a grant from participants which is used to help other participants when experiencing a disaster, is indicated at the beginning of the agreement stated in the Application for Sharia Life Insurance (SPAJS) Generali Indonesia Life Insurance. In SPAJS, in particular iPLAN Sharia, it was stated that a portion of the contribution funds had been agreed by the participants to be included in the tabarru' fund, which aims to assist sharia insurance participants who had experienced a disaster.

The position of Generali Indonesia Life Insurance as a tabarru' fund manager is implemented by the wakalah contract, where participants provide tabarru' funds to the manager, which is then distributed to participants who submit claims or are affected by disasters. This is based on DSNMUI fatwa number 53 on the third point that insurance companies act as administrators of grants (tabarru') based on the contractual agreement of the participants in addition to investment management. Meanwhile, the wakalah contract used by the company is wakalah bil ujrah agreement which is also following the DSN-MUI Fatwa number 52/DSNMUI/III/2006 were giving power of attorney by the participant to the insurance company in managing the participant funds there is a reward in the form of giving ujrah ( fee).

The focus of this research is to find out the company's analysis in allocating tabarru' fund underwriting surplus 'in the form of percentage distribution, time of distribution and revenue, the purpose of tabarru' fund underwriting surplus,' and the factors that influence it.

In this regard, the National Sharia Council of the Majelis Ulama Indonesia issued fatwa number 53/DSN-MUI/III/2006 concerning the Tabarru' Agreement on Sharia Insurance and Reinsurance which explains in the fifth point that if an 
Syarifudin, et al/Jurnal Ekonomi Syariah Teori dan Terapan Vol. 7 No. 9 September 2020: 18041817

insurance company has a surplus of the underwriting of tabarru' funds, then some alternatives are given as follows: (a) treated entirely as a reserve fund in tabarru' fund reserves; (b) saved partly in tabarru' fund reserves and partly distributed to eligible participants; and (c) is kept partly as a tabarru' fund reserve, partly allocated to the manager (insurance company), and partly distributed to participants as long as agreed by the participants.

From some of the terms of the distribution, Generali Indonesia Life Insurance for iPLAN Sharia products applies a third alternative with a percentage of $50 \%$ for tabarru' fund reserves, $30 \%$ for managers and $20 \%$ distributed to participants who meet the requirements as stated in the IPLAN Sharia product policy.

The above division can be distributed if the Generali Indonesia Life Insurance Sharia Unit experiences a tabarru' fund underwriting surplus in that period. The percentage provisions have been mutually agreed upon by several parties ranging from the Board of Directors, the Board of Sharia Division of Generali Indonesia, the Sharia Supervisory Board of Generali Indonesia, and other councils. They are guided by the provisions of the OJK (Otoritas Jasa Keuangan).

When the Generali Indonesia Life Insurance company experiences a tabarru' fund underwriting surplus, this company chooses the third alternative with the surplus allocation as follows: (1)
50\% deposited into tabarru' fund reserves', this is a form of company anticipation or precaution there is no shortage of tabarru' funds when a participant submits a claim. That way, bailout funds or gardh funds need not be issued by the insurance company and can reduce fears of losses to the Islamic insurance company; (2) $30 \%$ is allocated to the manager as the company's right to obtain a ujrah (fee) on the management of participant funds and obtain profit-sharing from the results of investment and wakalah bil ujrah as stated in DSN-MUI Fatwa number 53/DSNMUI/III/2006 fourth point verse three; and (3) $20 \%$ distributed to participants as the fulfillment of participant's rights in the tabarru' contract in obtaining a tabarru' fund underwriting surplus' as well as an effort to attract participants to reuse Generali Indonesia Life Insurance products.

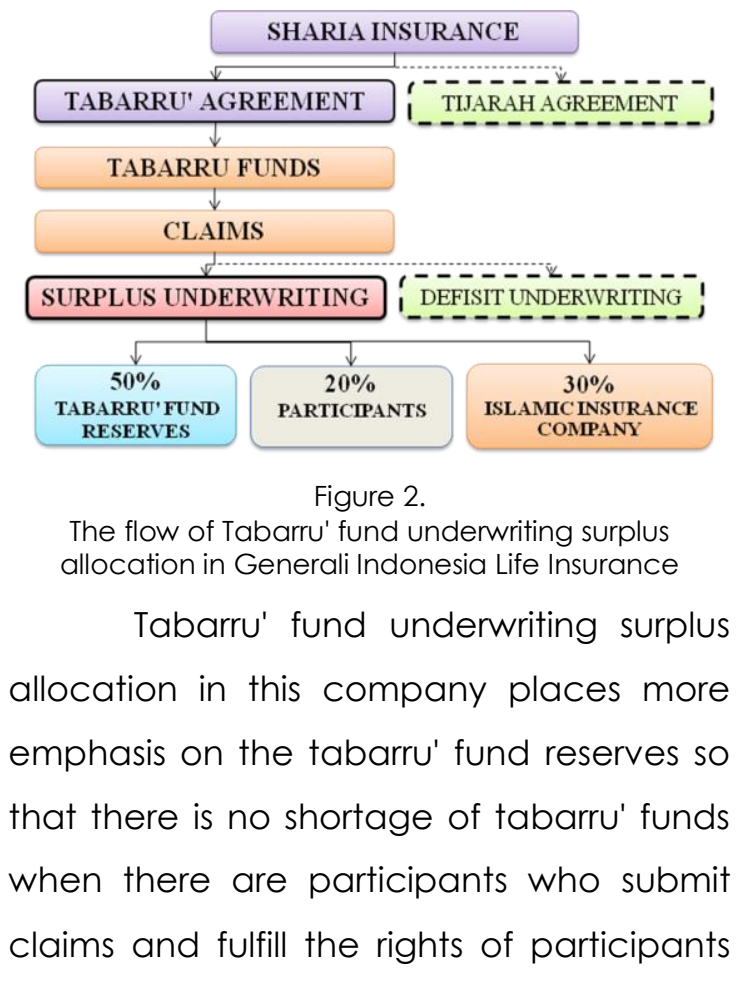

The flow of Tabarru' fund underwriting surplus location in Generali Indonesia Life Insurance

Tabarru' fund underwriting surplus allocation in this company places more that there is no shortage of tabaru' funds when there are participants who submit claims and fulfill the rights of participants 
Syarifudin, et al/Jurnal Ekonomi Syariah Teori dan Terapan Vol. 7 No. 9 September 2020: 18041817

and companies that have been clearly stated in the SPAJS iPLAN Sharia.

Tabarru' funds on Generali Indonesia Life Insurance are obtained from a portion of the contributions paid by participants. Tabarru' funds are then collected and later will be used for payment of claims of participants who experienced an accident. Fund management is also carried out separately from other funds under the fourth point paragraph, one of the DSNMUI fatwa number 53/DSN-MUI/III/2006. The results of the management of the tabarru' fund after being used for payment of participant claims and other insurance costs, can only be seen whether the insurance company is in a surplus or underwriting deficit.

As for participants who are entitled to a tabarru' fund underwriting surplus' iPLAN Sharia Indonesia products explained in the Sharia Life Insurance Policy Book, among others: (1) the participant's sharia insurance policy is 1 (one) year old; (2) all participant contribution obligations have been paid; (3) participants are not currently filing claims or requests for payment of death benefits or additional benefits (if any) listed on the policy; and (4) the policy is still valid in the period of tabarru' fund underwriting surplus distribution. The four provisions are based on the rules in Chapter III, article 6, paragraph 4 of the Financial Services Authority Regulation (POJK) No. 72/POJK.05/2016.
The distribution mechanism for the surplus underwriting of tabarru' 'iPLAN Sharia funds, as explained in the Generali Indonesia sharia insurance policy book, is no later than 120 (one hundred and twenty) after the end of the current year. The distribution will be calculated according to the provisions of the manager based on the proportion of each participant according to the agreement at the beginning. Eligible participants will receive a share of the tabarru' fund underwriting surplus allocation 'and are automatically distributed directly to the Islamic insurance policy account by the proportion of the contributions of each participant.

\section{v. CONCLUSIONS}

Based on the results of data analysis and discussion conducted by the author, the tabarru' fund underwriting surplus allocation at PT Asuransi Jiwa Generali Indonesia refers to fatwa number 53/DSN-MUI/III/2006 concerning the Tabarru' Agreement which is distributed to several parties with percentages and reasons as the following is $50 \%$ allocated to tabarru' fund reserves as a form of insurance company anticipation so that there is no shortage of tabarru funds when participants submit a claim, $30 \%$ is allocated to the manager as the fulfillment of company rights in obtaining ujrah (fees) on the management of tabarru funds' participants, as well as $20 \%$ is distributed to participants as fulfilling their rights in obtaining a tabarru' fund underwriting surplus. This division also aims to attract 
Syarifudin, et al/Jurnal Ekonomi Syariah Teori dan Terapan Vol. 7 No. 9 September 2020: 18041817

participants to reuse Generali Indonesia

Life Insurance products, especially sharia products.

\section{REFERENCES}

Agama Rl, Departemen. (2017). Al Qur'an dan terjemahnya. Jakarta: PT. Dinamika Cahaya Pustaka.

Ali, AM Hasan. (2004). Asuransi dalam perspektif hukum islam suatu tinjauan analisis historis, teoritis, dan praktek. Jakarta: Kencana.

Ali, Zainuddin. (2016). Hukum asuransi syariah. Jakarta: Sinar Grafika.

Alifianingrum, Rosyda dan Suprayogi, Noven. (2018). Faktor-faktor yang mempengaruhi surplus underwriting dana tabarru' pada perusahaan asuransi jiwa syariah. Jurnal Ekonomi Syariah Teori dan Terapan, 5(2), 143-157

Amrin, Abdullah. (2006). Asuransi syariah: Keberadaan dan kelebihannya di tengah asuransi konvensional. Jakarta: PT. Elex Media Komputindo.

Annabi, C. A., \& Ibidapo-Obe, O. O. (2017). Halal certification organizations in the United Kingdom: An exploration of halal cosmetic certification. Journal of Islamic Marketing, 8(1), 107-126. https://doi.org/10.1 108/JIMA-062015-0045

Arikunto, Suharsimi. (2010). Prosedur penelitian: Suatu pendekatan praktik. Jakarta: Rineka Cipta.

Dahlan, Abdul Aziz. (1996). Ensiklopedia hukum Islam. Jakarta: Ichtiar Baru van Hoeve.

Damayanti, F. E., \& Mawardi, I. (2016). Analisis faktor-faktor yang mempengaruhi surplus underwriting asuransi umum syariah di Indonesia. Jurnal Ekonomi Syariah Teori dan Terapan, 3(12), 989-1005.

Fadilah, A., \& Makhrus, M. (2019). Pengelolaan dana tabarru' pada asuransi syariah dan relasinya dengan fatwa dewan syariah nasional. Jurnal Hukum Ekonomi Syariah, 2(1), 87-103. https://doi.org/10.30595/jhes.v2i1.4 416
Faozi, M. M. (2016). Manajemen dana tabarru' pada asuransi takaful cabang Cirebon. Jurnal AlMustashfa, 4(2), 144-157.

Generali Indonesia, Unit Syariah. (2019). Ringkasan informasi produk iSALAAM. Jakarta: PT. Asuransi Jiwa Generali Indonesia.

Habibi, M. L., Toni, A., Candra, R., Islam, U., Sunan, N., \& Surabaya, A. (2017). Membangun integrated takaful dan wakaf model pemegang polis. Al-Uqud: Journal of Islamic Economics, 1 (2), 139-155.

Hardiyan dan Hazizah, Rosiana Nur. (2019). Pendukung keputusan dalam penentuan produk terbaik pada PT Asuransi Jiwa Generali. Jurnal SISFOKOM, 8(1), 31-38.

labal, Muhaimin. (2005). Asuransi umum syariah dalam praktik. Jakarta: Gema Insani.

Mapuna, H. D. (2019). Asuransi jiwa syariah: Konsep dan sistem operasionalnya. Al-Risalah, 19(1), 159-166.

Miftakhul Jannah, D., \& Nugroho, L. (2019). Strategi meningkatkan eksistensi asuransi syariah di Indonesia. Jurnal Maneksi, 8(1), 169-176.

Murti, T. W. (2017). Halal lifestyle and global trade. The 7th International Seminar on Tropical Animal Production Contribution of Livestock Production on Food Sovereignty in Tropical Countries, 2, 33-39. https://journal.ugm.ac.id/istapproc eeding/article/view/30115

Ozili, P. K. (2019). Non-performing loans in European systemic and nonsystemic banks. Journal of Financial Economic Policy, 12(3), 409-424. https://doi.org/10.1 108/JFEP-022019-0033

Othman, B., Shaarani, S. M., \& Bahron, A. (2016). Evaluation of knowledge, halal quality assurance practices and commitment among food industries in Malaysia. British Food Journal, 118(8), 2033-2052. https://doi.org/10.1108/BFJ-122015-0496

Peraturan Otoritas Jasa Keuangan Nomor 72/POJK.05/2016 tentang kesehatan keuangan perusahaan 
Syarifudin, et al/Jurnal Ekonomi Syariah Teori dan Terapan Vol. 7 No. 9 September 2020: 18041817

asuransi dan perusahaan reasuransi dengan prinsip syariah.

Qudsi, Devi Hunafa. (2018). Metode alokasi surplus underwriting dana tabarru' pada PT. Sunlife Financial Syariah (Analisis POJK No.72/POJK.05/2016 dan Fatwa DSN No.53/DSN-MUI/III/2006. Skripsi tidak diterbitkan. Jakarta: Universitas Islam Negeri Syarif Hidayatullah Jakarta.

Rijal, A. (2018). Pengetahuan konsumen terhadap IB Hasanah Card Bank BNI Syariah Cabang Surabaya. Adilla: Jurnal Ilmiah Ekonomi Syari'ah, 1(1), 117-139.

Sholihin, Ahmad Ifham. (2013). Buku pintar ekonomi syariah. Jakarta: Gramedia Pustaka Utama.

Soemitra, Andri. (2009). Bank \& lembaga kevangan syariah. Jakarta: Kencana Media Group.

Sula, Muhammad Syakir. (2004). Asuransi syariah; Life and general. Jakarta: Gema Insani Press.

Susyanti, Jeni. (2016). Pengelolaan lembaga kevangan syariah. Malang: Empat Dua.

The Pew Forum on Religion \& Public Life. (2016). Indonesia, negara berpenduduk muslim terbesar dunia. Diakses dari www. databoks.katadata.co.id/datapubl ish/ 2016/11/11/indonesia-negaraberpenduduk-muslim-terbesardunia

Tajerin, T., Sastrawidjaja, S., \& Yusuf, R. (2017). Tingkat kesejahteraan dan ketahanan pangan rumah tangga nelayan miskin: Studi Kasus di Kelurahan Marunda Baru, DKI Jakarta dan Desa Tanjung Pasir, Banten. Jurnal Sosial Ekonomi Kelautan dan Perikanan, 6(1), 83. https://doi.org/10.15578/jsekp.v6il. 5757

Toni, A., Candra, R., Sunan, U. I. N., \& Surabaya, A. (2019). Measuring professionalism in zakat management institution in East Java. 2019, 903-914. https://doi.org/10.18502/kss.v3il 1.4 058

Yudha, A. T. R. C., Pauzi, N. S., \& Azli, R. binti M. (2020). The synergy model for strengthening the productivity of indonesian halal industry. 4(28), 186-199. https://doi.org/10.26740/aluqud.v4n2.p186-199

Yudha, A. T. R. C., Ryandono, M. N. H., Rijal, A., \& Wijayanti, I. (2020). Financing model to develop local commodity business of East Java in Maqashid Syariah perspective. Test Engineering and Management, 83(3590), 3590-3595.

Oktoputra, Muhammad Sutomo. (2020). Interview.

Anggraini, Novita. (2020). Interview.

Eikema, Rene J. (2020) Interview. 